\title{
Mineralogical Horizon (A) Evaluation of a Toposequence of Soils Derived from Basalt by Thermal Analysis
}

\author{
Wilson Sacchi Peternele ${ }^{1^{*}}$, Antonio Carlos Saraiva da Costa ${ }^{2}$ \\ ${ }^{1}$ Department of Chemistry, Federal University of Rondônia, Porto Velho, Brazil \\ ${ }^{2}$ Department of Agronomy, State University of Maringá, Maringa, Brazil \\ Email: "wpeternele@yahoo.com.br
}

Received 6 June 2014; revised 7 July 2014; accepted 17 July 2014

Copyright (C) 2014 by authors and Scientific Research Publishing Inc.

This work is licensed under the Creative Commons Attribution International License (CC BY).

http://creativecommons.org/licenses/by/4.0/

\section{c) (i) Open Access}

\section{Abstract}

Thermogravimetry (TG) is a technique where the mass change of a substance is evaluated in function of temperature or time at a constant temperature while submitted to a controlled program in a specific environment. The minerals obtained from a clay fraction are highly susceptible to significant changes in composition as a response to thermal processes in function of temperature or dynamic as a function of time at a constant temperature. Thermogravimetric curves (TG) show mass changes preferentially during the heating processes. The DTG curve derived from the TG curve, shows changes in the inclination that are not exposed in the TG curve. DTG curve thus can show higher values of mass loss which are associated to an elevated degree of weathering for those reactions which involve mass changes, such as desorption, dehydration and reactions of dehydroxilation, observed in clay fraction without iron oxide-hydroxide, indicating kaolinite as a dominant mineral, with higher value $\mathbf{7 0 . 9 7 \%}$ of the fraction to soil class LVdf.

\section{Keywords}

Toposequence, Soil, Clay Minerals, TG, DTG

\section{Introduction}

Soil is the most important part of the geosphere [1]. It is also defined as a heterogeneous, natural, and opened system that exchanges energy and matter with the atmosphere, biosphere, and hydrosphere vicinities. Its characteristics vary with time and space according to the incessant chemical, physical and biological transformations that determine its fertility [2]. Kaolinite, gibbsite, oxihydroxide of Fe and $\mathrm{Al}$ and different quantities of smectites and/

\footnotetext{
${ }^{*}$ Corresponding author.
} 
or vermiculites are dominant minerals found in clay fraction from tropical, humid, and subtropical soils [3] [4].

Clays are essentially Al hydrated silicates, generally crystalline, called clay mineral. They can contain Fe and Mg and also other minerals, organic matter, and soluble salts. According to the chemical-physical point of view, clays can be considered mineral scatter systems with $2 \mu \mathrm{m}$ diameter particles predominance.

The accepted definition for thermal analysis was first offered by the Nomenclature Commission of the International Confederation of Thermal Analysis (ICTA), later adapted by the International Union of Pure and Applied Chemistry (IUPAC) as well as by the American Society of Tests of Matters (ASTM). The thermal analysis techniques are methods for variation measurement of any physical "organic or inorganic" matter property in function of time or temperature proposed by Mackenzi and quoted by Cavalheiro et al., (1995) [5] as thermogravimetric analysis (TG), differential scannig calorimetry (DSC), thermo-mechanical analysis (TMA), and thermo-physics properties (TPP).

As a particular case of thermo-analytic techniques, thermogravimetry follows up the mass physical property variation of a sample in function of temperature or time at a constant temperature. TG technique is essentially suitable whenever it is wanted to follow up mass variations in an experiment and its results are mainly of quantitative order. These results are later related to the volatile product formation when there is mass loss or atom or molecule incorporation (from liquefied gas) when there is mass increase. Evaluation of the main minerals found in clay fraction is presented in Table 1.

In the last decades, thermal-analytic techniques became important for the characterization and qualification of different materials. They can offer accurate thermal behaviour information of materials in a short period of time [7] [8]. The objective of this work is to evaluate mineralogy of the horizon (A) from four different soils from a region in Maringá (Paraná, Brazil). The soils developed in toposequence basalt derivate were evaluated by thermal analysis (TG) in nitrogen atmosphere and diffraction X-ray.

\section{Methodology}

The studied soils were classified according to the American System of Soil Classification as Haplortox, Paleudalf, Argiudoll and Endoaquerts, denominated here in this work as, LVdf "Latossolo Vermelho distroférrico", NVef "Nitossolo Vermelho eutroférrico", MTf "Chernossolo Argilúvico ferric" and VGo "Vertissolo Hidromórfico órtico", according to Embrapa (2006) [9]. Soil samples were collected in toposequence from Maringa’s soil in the State of Paraná (Brazil).

The samples were collected from the soil's superficial layer varying from a depth of 0 to $20 \mathrm{~cm}$, Afterwards the samples were dried at atmosphere temperature and sieved with a $2 \mathrm{~mm}$ polyethylene fine sieve. Special attention was given to the chemical characterization and quantification of the minerals present in the clay fraction from the fine earth dried at atmosphere temperature (TFSA).

\subsection{Chemical Characterization of Soils}

\subsection{1. $\mathrm{pH}$ Determination in Water and $\mathrm{CaCl}_{2}$} $10 \mathrm{~mL}$ of a soil sample and $25 \mathrm{~mL}$ of deionized distilled water were transferred to a $50 \mathrm{~mL}$ Erlenmeyer. The

Table 1. Temperature of the main events in some minerals of the clay fraction [6].

\begin{tabular}{ccc}
\hline Minerals & Temperature $\left({ }^{\circ} \mathrm{C}\right)$ & Chemical events \\
\hline Kaolinite & $500-600$ & Dehydroxylation \\
Halloisite & $100-200$ & Walter adsorved interlayer \\
& $500-600$ & Dehydroxylation \\
Montmorillonite & $100-250$ & Walter adsorved interlayer \\
& $600-750$ & Dehydroxylation \\
Beidelite & $100-250$ & Walter adsorved interlayer \\
Vermiculite & $500-600$ & Dehydroxylation \\
Gibbsita & 150 & Walter adsorved interlayer \\
Goethita & $250-350$ & Dehydroxylation \\
Dehydroxylation
\end{tabular}


mixture was agitated for 15 minutes and then it was let stand for 30 minutes. $\mathrm{pH}$ determination was performed using a digital $\mathrm{pH}$ indicator [10] [11].

A sample of $10 \mathrm{~mL}$ of soil and another of $25 \mathrm{~mL}$ of $\mathrm{CaCl}_{2} 0.01 \mathrm{~mol} \cdot \mathrm{L}^{-1}$ were transferred to $50 \mathrm{~mL}$ Erlenmeyer. The mixture was agitated for 15 minutes and then it was let stand for 30 minutes. $\mathrm{pH}$ determination was done using a digital $\mathrm{pH}$ indicator [10]-[12].

\subsubsection{Exchangeable Aluminium}

10 grams of dried and homogenized sample of soil was added to $125 \mathrm{~mL}$ Erlenmeyer flask, along with $100 \mathrm{~mL}$ of $\mathrm{KCl}$ solution $1.0 \mathrm{~mol} \cdot \mathrm{L}^{-1}$, and agitated at $220 \mathrm{rpm}$ for 15 minutes and rest for one night. After the settling time $20 \mathrm{~mL}$ pipet the supernatant into a $125 \mathrm{~mL}$ Erlenmeyer flask and exchangeable aluminium was quantified through extraction with $\mathrm{KCl} 1.0 \mathrm{~mol} \cdot \mathrm{L}^{-1}$ solution and titrated determination using $\mathrm{NaOH} 0.025 \mathrm{~mol} \cdot \mathrm{L}^{-1}$ solution and phenolphthaleine, as detector [11] [12].

\subsubsection{Potential Acidity}

A volume of $7.5 \mathrm{~mL}$ of calcium acetate $0.5 \mathrm{~mol} \cdot \mathrm{L}^{-1}$ with a $\mathrm{pH} 7$ (prepared in acetic acid) was added to a $0.5 \mathrm{~g}$ sample in a $250 \mathrm{~mL}$ Erlenmeyer, and then it was mechanically agitated with circular movements for 5 minutes and it was let stand for 12 hours. After that, $5 \mathrm{~mL}$ of the floating water were transferred to a $250 \mathrm{~mL}$ Erlenmeyer with phenolphthaleine drops $0.3 \%$ and was titrated with $\mathrm{NaOH} 0.05 \mathrm{~mol} \cdot \mathrm{L}^{-1}$, until it had color change [10]-[12].

\subsection{4. $\mathrm{K}^{+}$, $\mathrm{Ca}^{2+}$ e $\mathrm{Mg}^{2+}$ Determination}

Changeable content of potassium were obtained through extraction with Melich-1, Calcium and Magnesium with $\mathrm{KCl} 1.0 \mathrm{~mol} \cdot \mathrm{L}^{-1}$ solution and their determination was performed through fire emission photometry for $\left(\mathrm{K}^{+}\right)$ and atomic absorption spectrophotometry for $\left(\mathrm{Ca}^{2+} \mathrm{e} \mathrm{Mg}^{2+}\right)$, as Novais et al., (2007) [12].

\subsubsection{Values Sum of Bases (SB), Cation Exchange Capacity (CEC) and Aluminium Saturation (m)}

From K, Ca and Mg content the base sum (SB) was calculated. The cation exchange capacity (CEC) of soils was calculated by summing the exchangeable cations $\left(\mathrm{Ca}^{2+}, \mathrm{Mg}^{2+}\right.$ and $\left.\mathrm{K}^{+}\right)$with exchangeable acidity $\left(\mathrm{H}^{+}+\mathrm{Al}^{3+}\right)$, as Embrapa (1999) [13]. Base saturation levels (\% V) were calculated by dividing the sum of bases for the value of CEC. The aluminium saturation, value of $\mathrm{m} \%$, was calculated by dividing the amount of $\mathrm{Al}$ extracted in $\mathrm{KCl} 1.0$ $\mathrm{mol} \cdot \mathrm{L}^{-1}$ for the sum of these values plus the value of SB.

\subsubsection{Phosphorous Available}

$10 \mathrm{~cm}^{3}$ of soil sample were weighted in a $250 \mathrm{~mL}$ erlenmeyer and $100 \mathrm{~mL}$ of Melich-1 extract $(\mathrm{HCl} 0.05$ mol $\cdot \mathrm{L}^{-1}$ and $\mathrm{H}_{2} \mathrm{SO}_{4} 0.0125 \mathrm{~mol} \cdot \mathrm{L}^{-1}$ ) were added. This mixture was then agitated for about 5 minutes and let stand for 16 hours approximately. After this period, $5 \mathrm{~mL}$ of the floating water was used for calorimetric determination of $P$ with ammonium molybdate solution $0.016 \mathrm{~mol} \cdot \mathrm{L}^{-1}$, according Embrapa (1997) [10] and Camargo et al., (2009) [11].

\subsubsection{Total Organic Carbon Determination}

The organic carbon content was obtained through soil organic matter oxidation, humid way, (Walkley-Black method) with potassium dichromate in sulphuric acid medium.

A total of $0.5 \mathrm{~g}$ of the sample were weighted in a $250 \mathrm{~mL}$ Erlenmeyer. After that, $10 \mathrm{~mL}$ of $\mathrm{K}_{2} \mathrm{Cr}_{2} \mathrm{O}_{7} 0.5$ $\mathrm{mol} \cdot \mathrm{L}^{-1}$ and $20 \mathrm{~mL}$ of $\mathrm{H}_{2} \mathrm{SO}_{4} 98 \%$ were added, and mechanically agitated for a minute and then let stand for 30 minutes. After this period, $100 \mathrm{~mL}$ of deionized water were added, $10 \mathrm{~mL}$ of $\mathrm{H}_{3} \mathrm{PO}_{4}, 85 \%$, and 6 drops of diphenylamine $1 \%$ titrated with ammonium iron sulfate $0.5 \mathrm{~mol} \cdot \mathrm{L}^{-1}$ until its color changed from dark blue to green. The content of organic carbon from the soil sample was calculated with the used volume, according to Embrapa (1997) [10] and Novais et al., (2007) [12].

\subsubsection{Organic Matter Removal}

The organic matter oxidation present in the air dried sample (TFSA) was made using sodium hypochloride [14], while avoiding possible alterations in the minerals or the calcium oxalate formation due to the treatment with hydrogen peroxide [15]. 
The clay fraction without organic matter was collected after consecutive siphonings and submitted to flocculation with $\mathrm{MgCl}_{2} 1.0 \mathrm{~mol} \cdot \mathrm{L}^{-1}$ addition. The suspensions obtained were rinsed with deionized and distilled water to remove the salt excess. After that the samples were frozen in liquid Nitrogen and lyophilized with an (Alfa 1 2) Christ model, lyophilizer. When this process finished the dried material was ground in a mortar then sieved in a $0.84 \mathrm{~mm}$ mesh and put away for later analysis.

\subsubsection{Free Iron Content Determination}

The soil samples of the clay fraction were treated with sodium-bicarbonate-citrate-dithionite (DCB), according to Mehra and Jackson (1960) [16], to remove crystalline iron oxides and to determine the content of free Fe as $\left(\mathrm{Fe}_{2} \mathrm{O}_{3}\right)$.

In $100 \mathrm{~mL}$ tubes $2.0 \mathrm{~g}$ of each soil sample was added, $40 \mathrm{~mL}$ of sodium citrate $0.3 \mathrm{~mol} \cdot \mathrm{L}^{-1}, 5 \mathrm{~mL}$ of sodium bicarbonate $1.0 \mathrm{~mol} \cdot \mathrm{L}^{-1}$ and $1.0 \mathrm{~g}$ of powder sodium dithionite. The mixture was maintained in thermostat bath for 30 minutes at $65^{\circ} \mathrm{C}$. After this period, the sample received another portion of sodium dithionite, $1.0 \mathrm{~g}$, and was periodically agitated using a vortex at $80^{\circ} \mathrm{C}$ for complete dissolution of iron oxides observed by the grey colour of the residual solid matter [17]. After this dissolution, the solid material and the extracted were separated for centrifugation, rinsed with $100 \mathrm{~mL}$ distilled water to remove the salt excess, flocculated and lyophilized for future analysis and characterization.

\subsubsection{Aluminium and Iron Determination from DCB Extract}

The solution obtained from the previous item was used to evaluate total $\mathrm{Fe}$ and $\mathrm{Al}$ content getting their own concentration in those matters, as Coelho et al., (2010) [17].

The analytics determination of $\mathrm{Fe}$ and $\mathrm{Al}$ were analyzed in an atomic absorption spectrometer, model GBC $932 \mathrm{AA}, \lambda=372.0 \mathrm{~nm}$ using air-acetylene fire for iron and nitro-acetylene oxide in $\lambda=396.2 \mathrm{~nm}$ for aluminium.

\subsection{Soils Physic Characteristics}

\subsubsection{Total Specific Superficial Area $\left(\mathrm{ASE}_{\mathrm{T}}\right)$}

For the $\mathrm{ASE}_{\mathrm{T}}$ determination, a method based on polar liquid retention was used. An absorbed quantity is proportional to the particles areas [10]. Clay fractions of samples TFSA, $300 \mathrm{~g}$, were separated in small glasses and then received $1.5 \mathrm{~mL}$ ethylene glycol mono ethyl ether (EGME) to obtain saturation in all minerals and put in the desiccator with $\mathrm{CaCl}_{2}$ anhydrous. After vacuum application, order $0.6 \mathrm{~atm}$, for 12 hours, the samples were weighted many times until a constant weight was obtained.

The ASE value was determinate using this formula:

$$
\operatorname{ASE}\left(\mathrm{m}^{2} / \mathrm{g}\right)=a / 0.000286 b
$$

where $a$ is the EGME mass absorbed by the sample and $b$ is the dry sample at $105^{\circ} \mathrm{C}$ [10] [18].

\subsubsection{External Specific Superficial Area $\left(\mathrm{ASE}_{\mathrm{E}}\right)$}

The External Specific Superficial Area $\left(\mathrm{ASE}_{\mathrm{E}}\right)$, of the clay minerals was determinated by the Brunauer-EmmetTeller (BET) method, which consists of the measurement of nitrogenous absorbed by a solid sample at a constant temperature. This analysis determines the superficial area of a solid particle coated with $\mathrm{N}_{2}$. Approximately $300 \mathrm{mg}$ sample of the clay fraction of TFSA which was submitted to the $\mathrm{N}_{2}$ flow in a Monosorb equipment (Quantachrome Corporation, 1986), flux of gas nitrogen is evaluated in the process desorption of $\mathrm{N}_{2}$ by a surface area analyzer [18] [19].

\subsubsection{Thermogravimetric Analysis (TG)}

The content of kaolinite and gibbsite clay fractions of the soils were quantified by thermal analysis (TGA). Samples of approximately $6 \mathrm{mg}$ of material from clay fraction free of iron oxide and organic matter (SMO) were heated to $50^{\circ} \mathrm{C}$ to $1000^{\circ} \mathrm{C}$.

Determinations were performed on a Shimadzu thermal analyzer, TA 50 model, under $\mathrm{N}_{2}$ atmosphere with a flux of $20 \mathrm{~mL} \cdot \mathrm{min}^{-1}$ and the rate of heating $20^{\circ} \mathrm{C} \cdot \mathrm{min}^{-1}$ using a platinum pan [20]. The calibration curve was obtained under the same conditions with an empty pan, which was subtracted from the experimental curves. The analysis of the thermogram was performed using the TA-50WS computational program, which allowed deter- 
mination of the temperatures regarding DTG mass loss of minerals due to the associated water, hydroxyl groups and organic material present. Were used data of mass loss for the determination of clay minerals and gibbsite by stoichiometric relationships of its basic units.

The amount of expandable 2:1 clay minerals (smectite and/or vermiculite), of the clay fraction was determined by difference using the expression: 2:1 $=100 \%-(\% \mathrm{Fe}(\mathrm{DCB})+\%$ Gibbsite $+\%$ Kaolinite $)$ [21], following the fractionation observed by Sarwenay, (2008) [22].

\section{Results}

The Table 2 show chemical characteristics of horizon (A) for soils developed in toposequence in the region of Maringá in the State of Paraná, Brazil.

Conform observed in Table 2, the studied soils present different chemical characteristics. They share the absence of changeable Aluminium, except in class LVdf, with Aluminium saturation "M\%" equal 4, classifying it as the most intemperate class.

The increased values of the cationic exchange capacity (CEC) were also observed in the toposequence, favoured with the presence of clay minerals of high superficial area in the changing process and with little influence on the organic matter tenor which is constant among the evaluated classes. In general, the soils State of Paraná are originally well supplied with nutrients, except for sandy soils located in the northwest of Paraná.

The thermograms of the evaluated soils after the extractions with sodium bicarbonate citrate dithionite (DCB) and the removal of the organic matter with hypochlorite are presented in Figure 1.

In Figure 1 the maximum peaks dehydroxylation of gibbsite and kaolinite that happen at nearly $300^{\circ} \mathrm{C}$ and $600^{\circ} \mathrm{C}$ were observed, as well as the presence of two minerals in those temperatures for soils LVdf, NVef and MTf. Also, the absence of gibbsite in soil VGo was observed because of water presence, in other words, a total reductive environment, something common in this class. The quantities of minerals were obtained through stechiometric estimate, according to their dehydratation reactions using data mass loss of the thermograms, according Table 3.

The quantification of minerals 2:1 type: smectites and/or vermiculite was obtained by the $100 \%$ difference, in other words, all samples, except the iron extracted content with sodium-bicarbonate-citrate-dithionite. The con-

Table 2. Chemical characteristics of horizon A for soils from the toposequence from the Basalt derivates.

\begin{tabular}{|c|c|c|c|c|c|c|c|c|c|c|c|c|c|}
\hline \multirow{2}{*}{ Soil } & \multirow{2}{*}{$\mathrm{pH} \mathrm{H} \mathrm{H}_{2} \mathrm{O}$} & \multirow{2}{*}{$\mathrm{pH} \mathrm{CaCl}{ }_{2}$} & $\mathrm{Al}^{3+}$ & $\mathrm{H}^{+}+\mathrm{Al}^{3+}$ & $\mathrm{Ca}^{2+}+\mathrm{Mg}^{2+}$ & $\mathrm{Ca}^{2+}$ & $\mathrm{K}^{+}$ & SB & СTC & \multirow{2}{*}{ V\% } & \multirow{2}{*}{ M\% } & \multirow{2}{*}{$\frac{\mathrm{P}}{\mathrm{mg} \cdot \mathrm{dm}^{-3}}$} & \multirow{2}{*}{$\begin{array}{c}\mathrm{C} \\
\mathrm{g} \cdot \mathrm{dm}^{-3}\end{array}$} \\
\hline & & & \multicolumn{7}{|c|}{ - } & & & & \\
\hline LVdf & 5.50 & 4.70 & 0.30 & 5.34 & 4.18 & 2.22 & 0.55 & 6.95 & 12.29 & 56.55 & 4.00 & 2.00 & 16.69 \\
\hline NVef & 6.30 & 5.50 & 0.00 & 3.42 & 10.20 & 7.60 & 0.55 & 18.35 & 21.77 & 84.29 & 0.00 & 1.00 & 12.78 \\
\hline MTf & 6.20 & 5.50 & 0.00 & 3.97 & 22.50 & 16.12 & 0.69 & 39.31 & 43.28 & 90.82 & 0.00 & 17.00 & 14.00 \\
\hline VGo & 6.00 & 5.10 & 0.00 & 4.96 & 36.76 & 22.13 & 0.23 & 59.12 & 64.08 & 92.25 & 0.00 & 5.00 & 14.08 \\
\hline
\end{tabular}

$\mathrm{P}$ and $\mathrm{K}^{+}$extracted by Mehlich- $1, \mathrm{Ca}^{2+}, \mathrm{Mg}^{2+}$ and $\mathrm{Al}^{3+}$, extracted with $\mathrm{KCl} 1 \mathrm{~mol} \cdot \mathrm{L}^{-1}, \mathrm{H}^{+}+\mathrm{Al}^{3+}$ extracted with calcium acetate $0.5 \mathrm{~mol} \cdot \mathrm{L}^{-1}$ and silt and clay pipette method [10].

Table 3. Temperature values for dehydroxylation of gibbsite and silicate minerals and content of the clay fraction mass loss for different soils.

\begin{tabular}{|c|c|c|c|c|c|c|}
\hline \multirow{2}{*}{ Soil/horizon } & \multicolumn{3}{|c|}{ Gibbsite } & \multicolumn{3}{|c|}{ Silicate } \\
\hline & $\mathrm{T}_{\mathrm{i}}$ & $\mathrm{T}_{\mathrm{f}}$ & $\%$ & $\mathrm{~T}_{\mathrm{i}}$ & $\mathrm{T}_{\mathrm{f}}$ & $\%$ \\
\hline LVdf-A & 242.18 & 282.81 & 1.54 & 375.98 & 547.58 & 10.06 \\
\hline NVef-A & 249.61 & 280.81 & 0.75 & 380.66 & 547.58 & 9.37 \\
\hline MTf-A & 243.37 & 274.77 & 0.61 & 361.63 & 556.94 & 8.90 \\
\hline VGo-A & - & - & - & 361.93 & 550.70 & 7.49 \\
\hline
\end{tabular}

$\mathrm{T}_{\mathrm{i}}=$ Initial temperature; $\mathrm{T}_{\mathrm{f}}=$ final temperature; $\%$ = mass loss. 


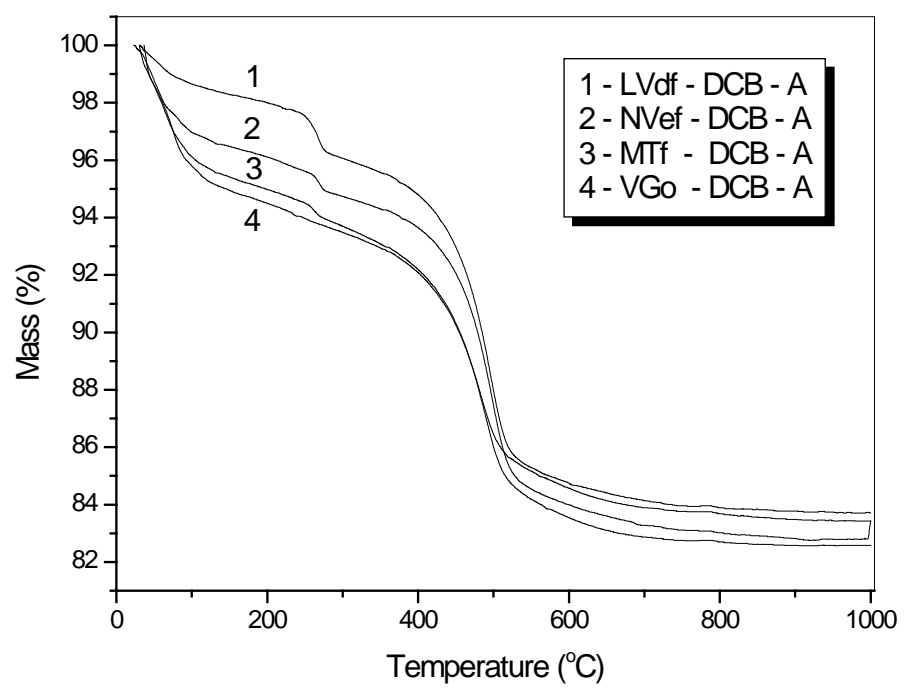

Figure 1. Iron-free clay fraction thermograms of horizon (A) for different soils of the toposequence treated with DCB.

tents gibbsite and kaolinite were determined from the evaluation of the thernograms. Thus, according to the stechiometric relations, in function of the water loss for each silicate, was observed higher values to mineral 2:1 type for less developed soils as VGo and kaolinite for more developed, as LVdf. Physical and mineralogical characteristics of the several soils developed in toposequence, evaluated from the clay fraction and treated with sodium bicarbonate citrate dithionite (DCB), are presented in Table 4.

It can be observed that gibbsite content decreases in the toposequence when the soils present little developed characteristics because of the low silica loss in the system. Nevertheless, stechiometric estimates show kaolinite decrease and expandable clay higher for mineral 2:1 type with the reduction of Iron and aluminium oxi-hydroxide as a consequence of reductive environment because of water presence.

In Table 4 the physical and mineralogical characteristics of the clay fraction can be also observed, where kaolinite is the most abundant mineral found in the clay fractions of the soils. Then there are $\mathrm{Fe}$ and $\mathrm{Al}$ oxi-hydroxides, and in less quantities, mineral 2:1 type decreasing for LVdf soil classifying it as the most weathering among the studied classes. These soils present clay characteristics with low sand content even though they present with Arenito Caiuá contribution, which can be found in countries around Brazil. The values that were found for $\mathrm{ASE}_{\mathrm{T}}$ (total) in the soils through EMEG method are significantly increased from LVdf to VGo classes as a result of the evaluation of the total area of the matters, because of the presence of clay minerals with high superficial area, such as: 2:1 type. For ASE $\mathrm{E}_{\mathrm{E}}$ (external) $\left(\mathrm{BET}_{\mathrm{N}} \mathrm{N}_{2}\right)$ there is also an increasing level in the toposequence, except for the MTf class, which presents $26.70 \%$ sand content, reducing the outer superficial area of the class. LVdf and NVef soil have high porosity physical characteristics and low density. Its mineralogy is called Fe oxides, Kaolinite and gibbsite. MTf and VGo soils are developed in irregular landscapes and water sheet presence and are described as the youngest soils for being less weathering and having increased quantities of minerals 2:1 type smectites and/or vermiculite.

The mineralogical evaluation of a soil class is commonly done in horizon B and/or C. The difratograms obtained in "horizon B and/or C" of the mineralogical evaluation for the studied soils, after the extraction with sodium bicarbonate citrate dithionite and the removal of the organic matter with hypochloride sodium, to confirm the presence of the clay minerals referred in horizon A, analysed at first by TG, after the different chemical treatments used in their division, as presented in Figure 2.

It can be observed in Figure 2, that the VGo class of minerals evaluated by DRX developed in toposequence are the same in all classes, differing only in their own ratios and chemical-physical properties, according to Table 2 and Table 3.

It is observed as well with greater degree weathering soils, like LVdf, have a higher content of kaolinite (clay minerals 1:1) than the clay minerals 2:1 type, something that is not the same for less developed soils like VGo, the last toposequence class, which is observed through thermogravimetric analysis (TG), according to the values presented in Table 4. 


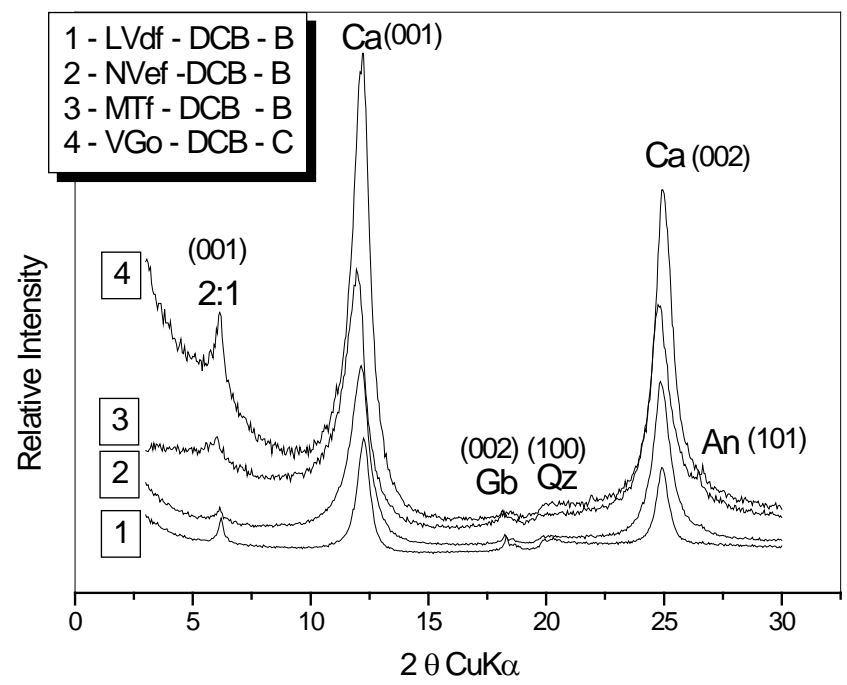

Figure 2. X-rays difratograms of the samples guided by the ironfree clay fraction of horizon B and/or C for the different soils of the toposequence after treaties with DCB and solvation with $\mathrm{Mg}$ $25^{\circ} \mathrm{C}$. $\mathrm{Ca}=$ kaolinite; $\mathrm{Gb}=$ gibbsite; $\mathrm{Na}=$ anatase; $2: 1=$ smectites and/or vermiculite and $\mathrm{Qz}=$ quartz.

Table 4. Physical and mineralogical characteristics of horizon (A) for soils of the toposequence of the Basalt derivative.

\begin{tabular}{|c|c|c|c|c|c|c|c|c|c|c|}
\hline Soil & $\mathrm{ASE}_{\mathrm{E}} \cdot \mathrm{dm}^{-3} \mathrm{CMO}$ & $\mathrm{ASE}_{\mathrm{T}} \cdot \mathrm{dm}^{-3} \mathrm{CMO}$ & Sand & Silt & Clay & Fe DCB & Al DCB & $\mathrm{Gb}$ & $\mathrm{Ct}$ & Type 2:1 \\
\hline & $\mathrm{m}^{2} / \mathrm{g}$ & $\mathrm{m}^{2} / \mathrm{g}$ & \multicolumn{3}{|c|}{----------------\%---------------' } & \multicolumn{5}{|c|}{-------------------------\%---------------------- } \\
\hline LVdf & 47.15 & 71.79 & 13.20 & 16.16 & 70.64 & 19.50 & 1.77 & 4.23 & 70.97 & 3.53 \\
\hline NVef & 52.00 & 106.74 & 11.97 & 18.36 & 69.17 & 20.12 & 2.05 & 2.09 & 67.45 & 8.29 \\
\hline MTf & 41.20 & 131.82 & 26.70 & 32.33 & 40.97 & 16.37 & 1.82 & 1.83 & 63.65 & 16.33 \\
\hline VGo & 81.17 & 246.81 & 18.43 & 23.13 & 58.44 & 8.01 & 0.75 & 0.00 & 55.13 & 36.11 \\
\hline
\end{tabular}

$\mathrm{GB}=$ gibbsite; $\mathrm{Ct}=$ kaolinite; type 2:1: vermiculite and/or smectite; $\mathrm{CMO}=$ with organic matter.

As soils present little developed characteristics, there is a low content in expandable minerals, smectites and/ or vermiculites class. In other words, the weathering happens with the decomposition of primary minerals according to the sequence (primary $\rightarrow 2: 1 \rightarrow 1: 1 \rightarrow 0: 1$ ), like olivine and pyroxenes for montmorillonite for kaolinite and gibbsite.

Thus, both techniques (TGA and XRD), can be used in the mineralogical evaluation of the soils developed in toposequence, as far as their mineral subdivision processes, silicate. Fe and Al oxi-hydroxide and organic matter are observed with the objective to eliminate interference in decomposition process thermal for a better of dehydration and dehydroxylation evaluation of the minerals.

\section{Conclusions}

The mineralogical evaluation by thermal analysis (TG) and X ray diffraction (XRD), presents the kaolinite as the dominant mineral in soil. The most developed class of soil is that which has a higher content of the mineral kaolinite and gibbsite with few minerals expandable, that is, content of smectite mineral and/or vermiculite in small quantities.

The mass loss of the mineral kaolinite decreases from LVdf class to VGo and follows the evaluations of the most developed soils. In other words, larger weathering of the soils higher clay content with kaolinite predominance. 
The thermogravimetric analysis seems to be an interesting technique in quantification of the compounds presented by soils, provided that are separated, silicate, iron oxi-hydroxide and aluminium besides organic matter, should be observed in process.

\section{References}

[1] Singh, R., Singh, P.K. and Singh, G. (2007) Evaluation of Land Degradation Due to Coal Mining-A Vibrant Issue. 1st International Conference on MSECCMI, New Delli, 129-133.

[2] Ranno, S.K., Silva, L.S., Gatiboni, L.C. and Rhoden, A.C. (2007) Capacidade de adsorção de fósforo em solos de várzea do Estado do Rio Grande do Sul. Revista Brasileira de Ciencia do Solo, 31, 21-28. http://dx.doi.org/10.1590/S0100-06832007000100003

[3] Silva Neto, L.F., Inda, A.V., Bayer, D.P.D. and Tonin, A.T. (2008) Óxidos de ferro em Latossolos tropicais e subtropicais brasileiros em plantio direto. Revista Brasileira de Ciencia do Solo, 32, 1873-1881. http://dx.doi.org/10.1590/S0100-06832008000500008

[4] Fitzpatrick, R.W. (2009) Soil: Forensic Analysis. In: Jamieson, A. and Moenssens, A., Eds., Wiley Encyclopedia of Forensic Science, John Wiley \& Sons, Ltd., Chichester, 2377-2388. http://dx.doi.org/10.1002/9780470061589.fsa096

[5] Cavalheiro, E.T.G., Ionashiro, M., Breviglieri, S.T., Marino, G. and Chierice, G.O. (1995) A influência de fatores experimentais nos resultados de análises termogravimétricas. Química Nova, 18, 305-308.

[6] Tan, K.H. and Hajek, B.F. (1977) Thermal Analysis of Soil. In: Dixon, J.B., Weed, S.B., Kittrick, J.A., Milford, M.H. and White, J.L., Eds., Minerals and Soil Environments, Madison, 865-884.

[7] Barros, N., Salgado, J., Vilanueva, M., Rodriguez-Anón, J., Proupin, J., Feijóo, S. and Martín-Pastor, M. (2010) Application of DSC-TG and NMR to Study the Soil Organic Matter. Journal of Thermal Analysis and Calorimetry, 104, 5360. http://dx.doi.org/10.1007/s10973-010-1163-4

[8] Duguy, B. and Rovira, P. (2010) Differential Thermogravimetry and Differential Scanning Calorimetry of Soil Organic Matter in Mineral Horizons: Effect of Wildfires and Land Use. Organic Geochemistry, 41, 742-752. http://dx.doi.org/10.1016/j.orggeochem.2010.05.015

[9] Empresa Brasileira de Pesquisa Agropecuária-EMBRAPA (2006) Centro Nacional de Pesquisa de Solos. Sistema brasileiro de classificação de solos. 2nd Edition, Rio de Janeiro, 306.

[10] Empresa Brasileira de Pesquisa Agropecuária_EMBRAPA (1997) Manual de métodos de análise de solo. 2nd Edition, Rio de Janeiro, 212.

[11] Camargo, O.A., Moniz, A.C., Jorge, J.A. and Valadares, J.M.A.S. (2009) Métodos de análises química, mineralógica e física de solos do Instituto Agronômico de Campinas. Governo do Estado de São Paulo, Boletim No. 106, 77.

[12] Novais, R.F., Alvarez, V., Barros, N.F., Fontes, R.L.F., Cantatutti, R.B. and Neves, J.C.L. (2007) Fertilidade do Solo. Universidade Federal de Viçosa, Viçosa, 1017-1025.

[13] Empresa Brasileira de Pesquisa Agropecuária_EMBRAPA (1999) Sistema brasileiro de classificação de solos. Centro Nacional de Pesquisa de Solos, Rio de Janeiro, 412.

[14] Lavkulich, L.M. and Wiens, J.H. (1970) Comparison of Organic Matter Destruction by Hidrogen Peroxide and Sodium Hipochlorite and Its Effects on Selected Mineral Constituents. Proceedings of Soil Science Society of America, 34, 755-758. http://dx.doi.org/10.2136/sssaj1970.03615995003400050025x

[15] Dowdy, R.H. (1994) Preconcentration Techniques in Soil Mineralogical Analyses. In: Amonette, J.E. and Zelazny, L.W., Eds., Quantitative Methods in Soil Mineralogy, Madison, 236-262.

[16] Mehra, O.P. and Jackson, M.L. (1960) Iron Oxide Removal from Soils and Clay by a Dithionite-Citrate System Buffered with Sodium Bicarbonate. Clays Clay Minerals, 7, 317-327. http://dx.doi.org/10.1346/CCMN.1958.0070122

[17] Coelho, M.R., Vidal-Torrado, P., Perez, X.L.O., Martins, V.M. and Vásquez, F.M. (2010) Fracionamento do alumínio por técnicas de dissoluções seletivas em espodossolos da planície costeira do Estado de São Paulo. Revista Brasileira de Ciencia do Solo, 34, 1081-1092. http://dx.doi.org/10.1590/S0100-06832010000400008

[18] Souza Junior, I.G., Saraiva Da Costa, A.C., Sambatti, J.A., Peternele, W.S., Tormena, C.A., Montes, C.R. and Clemente, C.A. (2007) Contribuição dos constituintes da fração argila de solos subtropicais à área superficial específica e a capacidade de troca catiônica. Revista Brasileira de Ciencia do Solo, 31, 1355-1365. http://dx.doi.org/10.1590/S0100-06832007000600014

[19] Desauziers, V., Castre, N. and Le Cloirec, P. (1997) Soprtion of Methylmercury by Clays and Mineral Oxides. Environmental Technology, 18, 1009-1018. http://dx.doi.org/10.1080/09593331808616620

[20] Pergher, S.B.C., Corna, A. and Fornés, V. (1999) Preparación y propriedades de uma arcilla montmorillonita pilareada com polihidroxicationes de aluminio. Quimica Nova, 22, 693-709. 
http://dx.doi.org/10.1590/S0100-40421999000500013

[21] Costa, A.C.S., Gigham, J.M., Rhoton, F.E. and Traina, S.J. (1999) Quantification and Characterization of Maghemite in Soils Derived from Volcanic Rocks in Southern Brazil. Clays and Clay Minerals, 47, 466-473. http://dx.doi.org/10.1346/CCMN.1999.0470408

[22] Sarwenay, A. (2008) Clay Mineral Quantification Using Gravimetric Analysis. Dissertation for the Degree of Master of Science in Civil Engineering, The University of Texas at Arlington, Arlington, 84. 
Scientific Research Publishing (SCIRP) is one of the largest Open Access journal publishers. It is currently publishing more than 200 open access, online, peer-reviewed journals covering a wide range of academic disciplines. SCIRP serves the worldwide academic communities and contributes to the progress and application of science with its publication.

Other selected journals from SCIRP are listed as below. Submit your manuscript to us via either submit@scirp.org or Online Submission Portal.
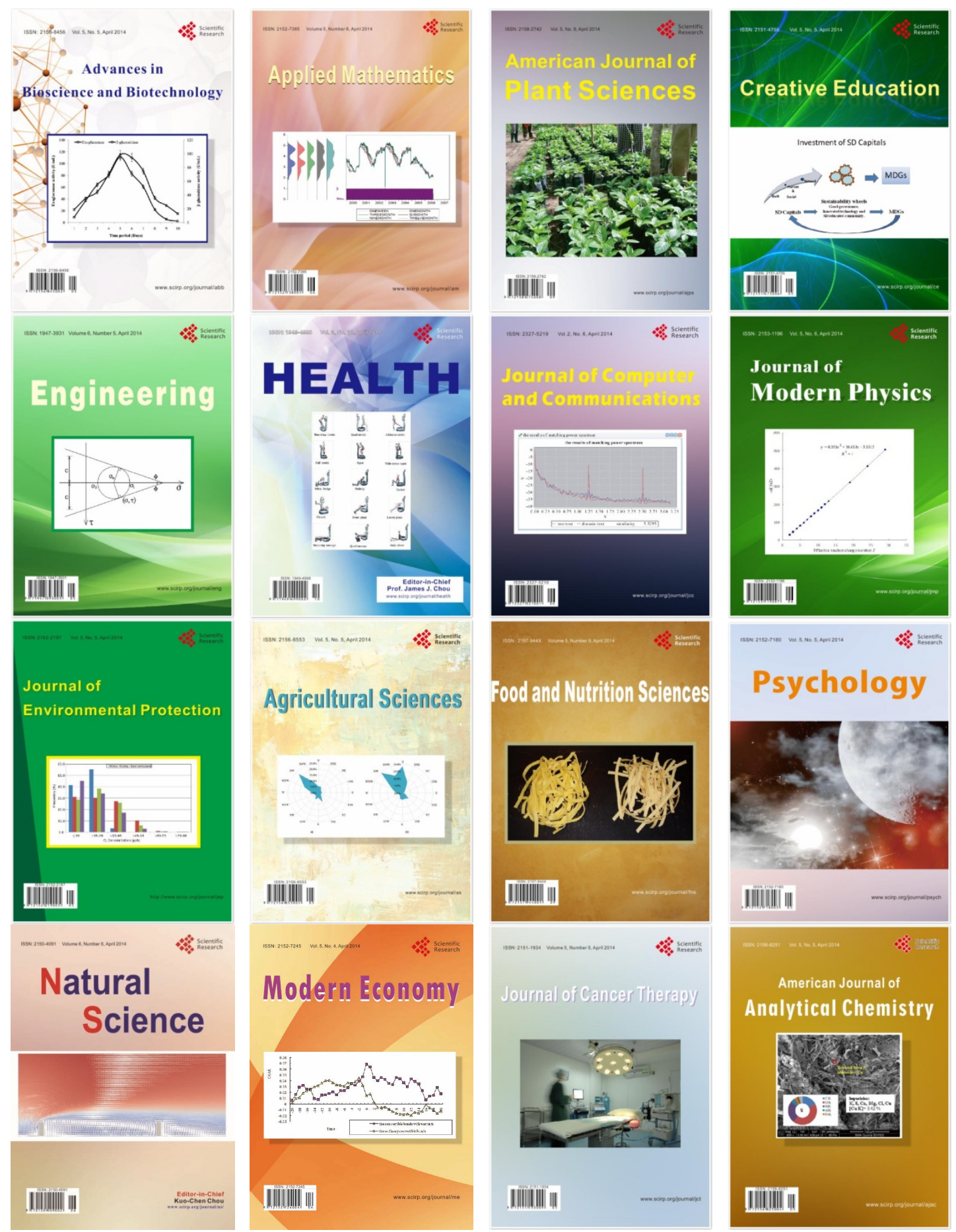